\title{
Autolysis of Rice Bran Phytate in Long-Term Study on Batch Fermentor
}

\author{
Abd-ElAziem Farouk ${ }^{\text {** }}$, N. Thoufeek Ahamed ${ }^{1}$, \\ Anis Shobirin Meor Hussin ${ }^{2,3}$ and Othman AlZahrani ${ }^{1}$ \\ ${ }^{1}$ Molecular Biotechnology Research Unit, Department of Biotechnology, Faculty of Science, \\ Taif University, Al-Hawiya 888, Kingdom of Saudi Arabia \\ ${ }^{2}$ Department of Food Science, Faculty of Food Science and Technology, Universiti Putra \\ Malaysia, 43400 UPM Serdang, Selangor Darul Ehsan, Malaysia \\ ${ }^{3}$ Halal Products Research Institute, Universiti Putra Malaysia, 43400 UPM Serdang, \\ Selangor Darul Ehsan, Malaysia \\ *Corresponding author
}

\section{A B S T R A C T}

Microorganisms especially bacteria produce a diverse of phytate-degrading enzymes. Rice bran is excellent media for bacterial growth and enzymes secretion. The aim of the study was autolysis of rice bran phytate $(6 \%)$ in long-term on batch fermentor (with constant

Keywords

Autolysis,

Fermentation, Phytate-degrading enzymes, Rice bran.

Article Info

Accepted:

04 October 2017

Available Online:

10 December 2017 agitator speed $(300 \mathrm{rpm})$ and fixed air flow rate $\left(0.5 \mathrm{~kg} / \mathrm{cm}^{2}\right)$. The phytase production in the fermentor was with gradual color change from initial light green to dense green during the fermentation processes. The $\mathrm{pH}$ and temperature changes during production of phytase in the rice bran media over 10 weeks were observed. Initial 3 weeks, a reduction in $\mathrm{pH}$ from $\mathrm{pH} 6$ to $\mathrm{pH}$ 4.2. After the middle of $4^{\text {th }}$ week and $5^{\text {th }}$ week considerable increase in $\mathrm{pH}$ towards the neutral range was observed i.e. from $\mathrm{pH} 6.2$ to $\mathrm{pH} 6.99$. In the $5^{\text {th }}$ and $6^{\text {th }}$ weeks the $\mathrm{pH}$ range was found to be $\mathrm{pH} 7$ to $\mathrm{pH} 7.9$. Starting from the beginning of $8^{\text {th }}$ week to $10^{\text {th }}$ week $\mathrm{pH}$ was in the near alkaline range $\mathrm{pH} 8-\mathrm{pH}$ 8.2. The temperature of the media during the initial stages of fermentation for first 3 weeks was $22-25^{\circ} \mathrm{C}$. Increase in temperature was noticed after the end of the third week. The remaining weeks from 3 to 10 the temperature range was $25^{\circ} \mathrm{C}-29^{\circ} \mathrm{C}$. The temperature of the media inside the fermentor was in between $22^{\circ} \mathrm{C}$ and $29^{\circ} \mathrm{C}$ throughout the study (environment temperature $20-40^{\circ} \mathrm{C}$ ). Enzymatic partitional hydrolyzed of rice bran phytate into lower myoinsitol phosophates will have many health benefits applications.

\section{Introduction}

Phytate (myo-inositol hexakisphosphates), a phosphorylated derivative of myo-inositol, is widely distributed in plants, particularly in cereals and legumes, such as corn, soybean, wheat bran, rice bran, cotton seeds, rape seeds and soybean with a concentration range between $0.4 \%$ to $6.4 \%$. Phytases are capable of hydrolyzing phytates, the major storage form of phosphate in plant seeds and pollen (Konietzny and Greiner, 2002) to a series of lower phosphate esters of myo-inositol and phosphate. Phytase is an extracellular enzyme that can catalyse the hydrolysis of phytic acid to inorganic monophosphate and lower myoinositol phosphates. Phytases are 
widespread in the nature because they can be found in the animals, plants, and microorganisms. Generally, phytase activity of animals is negligible compared to their plant and microbial counterparts (Weremko et al., 1997).

Phytases decomposes Phytate, which is the primary storage form of phosphate in plants. All commercial phytase preparations contain microbial enzymes which are produced by fermentation. A wide variety of phytases were discovered and characterized in the last 10 years. Different formulation technologies are used to produce enzyme powders that retain enzyme activity, are stable in application, resistant against high temperatures, dust-free, and easy to handle (Mukesh Kumar, 2011).

Phytases are widely distributed in nature (Irving, 1980; Nayini and Markakis, 1986) for example in plants, microorganisms and certain animal tissues. Phytase supplementation has been found to increase not only the growth rate of monogastric animals but also the efficiency of phosphate utilization in feeds, which significantly reduces phosphorus excretion and the chances of environmental pollution (Kornegay, 1996). This is because the undigested Phytate phosphorus is excreted in manure and poses serious phosphorus pollution problem, contributing to the eutrophication of surface waters in areas of intensive livestock production (Reddy et al., 1982; Wodzinski and Ullah, 1996). Phytase can be also applied as cosmetic additives and plant nutrition (Koshy et al., 2012; Gujar et al., 2013). Phytase acts as an anti-nutrient by binding to proteins and by chelating minerals (Cheryan, 1980; Reddy et al., 1989)., The addition of phytase can improve the nutritional value of plant-based foods by enhancing protein digestibility and mineral availability through Phytate hydrolysis during digestion in the stomach or during food processing (Reddy et al., 1989; Sandberg and Andlid, 2002).
Phytase is very sensitive to $\mathrm{pH}$ and temperature, the utilization of phytase in fish feed is still on its first stage compared with that of in poultry and swine feed (Ling and Wang, 2007). The Phytate-degrading enzymes (Hussain et al., 2009, 2010, 2015) also can be divided into two types based upon their optimal $\mathrm{pH}$. These are the acid Phytatedegrading enzymes with a $\mathrm{pH}$ optimum around 5.0, and the alkaline Phytatedegrading enzymes with a $\mathrm{pH}$ optimum around 8.0 (Vucenik and Shamsuddin, 2003; Farouk et al., 2015).

Most of the Phytate-degrading enzymes belong to the acid type. However, it has to be taken into account that microbial phytases of different sources can differ in their bioefficacy per unit (Konietzny and Greiner, 2002; Hussain et al., 2009, 2010, 2015). According to Lan, et al., 2002 proteins and minerals in standard and purified rice bran phytic acid Rice bran, consisting of pericarp, aleurone and germ, has a high concentration of Phytic acid ranging from 5.94 to

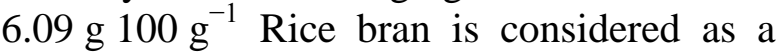
rice industry by-product and corresponds to $10 \mathrm{~g} 100 \mathrm{~g}^{-1}$ of integral rice grain. It is used for oil extraction, feed production and also as an ingredient in the formulation of food products because of its protein, lipid, mineral and antioxidant (Parrado et al., 2006). Rice bran was stated as the best carbon source for the production of phytase (Lan et al., 2002).

Salts of phytic acid, designated as phytates, are regarded as the primary storage form of both phosphate and inositol in plant seeds and grains. Phytate is formed during maturation of the plant seed and in dormant seeds it represents $60-90 \%$ of the total phosphate (Loewus, 2002). Phytate is therefore a common constituent of plant-derived foods. Depending on the amount of the plant-derived foods in the diet and the grade of food processing; the daily intake of phytate can be as high as $4500 \mathrm{mg}$. On an average, daily 
intake of phytate was estimated to be 2000$2600 \mathrm{mg}$ for vegetarian diets as well as diets of inhabitants of rural areas in developing countries and 150-1400 mg for mixed diets (Reddy, 2002).

Rice bran, a by-product of rice milling, is usually either discarded as a waste or used to feed poultry and livestock (Yusoff et al., 2010). The Crude protein content in defatted rice bran is higher $(20.02 \%)$ than corn $(9.53 \%)$ and lesser than soya bran $(20.02 \%)$, where Crude fiber content in rice bran is higher $(10.73 \%)$ than both corn $(4.78 \%)$ and soya bran (3.32\%) (Moreira, 2003). The Phytate-P contents in rice bran and Wheat bran are $14.17 \mathrm{~g} / \mathrm{kg}$ and $8.36 \mathrm{~g} / \mathrm{kg}$ and their proportion \% was 79.5 and 76.3 respectively (Cao et al., 2007).

Aspergillus oryza has $\mathrm{pH}$ optimum 5.5 and temperature optimum $50^{\circ} \mathrm{C}$ with specific activity at $37^{\circ} \mathrm{C}$ was $11 \mathrm{U} / \mathrm{mg}$ was stated (Greiner and Konietzny, 2006; Weremko et al., 1997). The Content of organic, inorganic and total phosphorus, total nitrogen, phosphorus, total nitrogen, soluble and total proteins and minerals in standard and purified rice bran phytic acid were analysed by Canan (2011).

Rice bran, consisting of pericarp, aleurone and germ, has a high concentration of phytic

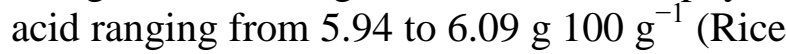
bran is considered as a rice industry by-

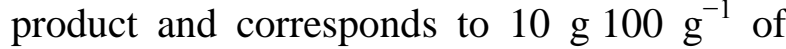
integral rice grain. It is used for oil extraction, feed production and also as an ingredient in the formulation of food products because of its protein, lipid, mineral and antioxidant contents (Paraddo et. al., 2011).

In 2010 the technical enzymes generated was $\$ 1.10$ billion and the world market for industrial enzymes surpassed \$6 billion in 2016 (Anon, 2012). The continuously growing bio-processing industry demands inexpensive and renewable material. A study of microbial phytase production in the rice bran of media in a batch fermentor was carried out. The effect of $\mathrm{pH}$, temperature and dissolved oxygen content during production were observed. Phytase production was influenced by the $\mathrm{pH}$ and temperature since it has sensitive protein nature of denaturation. In whole grain cereals such as corn, wheat and rice, the ranges of phytic acid is from 1.5 to $6.4 \%$ while defatted and dehulled oilseed meals such as soy, peanut and sesame contain $1.5 \%$ or more of the compound (Grases, 2004). Phytic acid is primarily found in the outer layers of rice bran. Rice bran is a byproduct of rice milling to produce white rice to fulfill its desirability.

\section{Materials and Methods}

\section{Rice bran media}

For the autolysis of rice bran study, six percent of rice bran (source?) was used in fermentation for 10 weeks in a batch fermentor (model, country).

The changes of $\mathrm{pH}$, temperature and dissolved oxygen content in the $6 \%$ rice bran without any additives such as tryptone, yeast, $\mathrm{NaCl}$, peptone, meat extract, $\mathrm{MgSO}_{4}, \mathrm{MgCl}_{2}, \mathrm{KCl}$, $\mathrm{CaCl}_{2}$, casein (pancreatic digest) was selected to know the natural outcome. The media's initial $\mathrm{pH}$ was adjusted to $\mathrm{pH} 7$. The reduction in $\mathrm{pH}$ i.e. acidic range was noticed in the initial stages of fermentation and the shoot up at the later stage denoted the production of active phytase.

The temperature $\left({ }^{\circ} \mathrm{C}\right), \mathrm{pH}$ and dissolved oxygen (DO) observation was carried out for 10 weeks in the batch fermentor and results are shown in Figure 2 and 3 respectively.

\section{Production}


The enzyme production was carried out by batch fermentation using production broth (rice bran extract - 6\%; $\mathrm{pH}-6.5$, distilled water $-7000 \mathrm{ml}$ ). The medium was autoclaved at $121^{\circ} \mathrm{C}$ at $15 \mathrm{lbs}$. Fermentation under room temperature $\left(25-30^{\circ} \mathrm{C}\right)$ for 48 days at agitator speed at $300 \mathrm{rpm}$ and at fixed air flow rate $(0.5 \mathrm{~kg} / \mathrm{cm} 2)$. The temperature study was carried out for 10 weeks in the batch fermentor and the results are shown in Figure 1.

\section{Sample preparation}

Samples for phytase enzyme activity assays were prepared by centrifugation of $1.5 \mathrm{~mL}$ bacterial culture from the fermentor at 13000 rpm for 1 min (Idriss et al., 2002). The cellfree supernatant was separated for phytase assay. Phytase measurements carried out at $28^{\circ} \mathrm{C}$. The reaction was initiated with the addition of phytase enzyme from each day. After 30 minutes incubation, the liberated inorganic phosphate was measured using a modification of the ammonium molybdate method (Heinonen and Lahti, 1981). A freshly prepared solution of acetone: $5 \mathrm{~N}$ sulfuric acid: $10 \mathrm{mM}$ ammonium molybdate $(2: 1: 1 \mathrm{v} / \mathrm{v})$ and thereafter $100 \mu \mathrm{L}$ of $1.0 \mathrm{M}$ of citric acid were added to $400 \mu \mathrm{L}$ of the phytase assay mixture. The cloudiness was removed by centrifugation in a centrifuge at $13000 \mathrm{rpm}$ for $10 \mathrm{~min}$ prior to the measurement of absorbance at $355 \mathrm{~nm}$ in a UV double beam spectrophotometer In order to quantify the phosphate released; a calibration curve was constructed over the range of 5 to $1200 \mathrm{mM}$ phosphate.

\section{Production of phytase in rice bran media}

The agitator speed was selected at $300 \mathrm{rpm}$ since the rupture of bacterial cells may happen above this speed. Autolysis of rice bran showed the initial $\mathrm{pH}$ of the cultivation media which is different according to the each day of fermentation. Figure 2 shows the $\mathrm{pH}$ at different days and Figure 4 shows the fermentor samples variation in the absorption at $355 \mathrm{~nm}$. The absorption was significantly higher in the $6^{\text {th }}$ week at $26^{\circ} \mathrm{C}$ with $\mathrm{pH} 7.62$. The pattern was nearly similar on $7^{\text {th }}$ week but the absorption values decreased in after $8^{\text {th }}$ week to $10^{\text {th }}$ weeks. It is assumed from study that the phytase production was significantly higher at $26^{\circ} \mathrm{C}$.

\section{Results and Discussion}

The results of the present study showed that in this selected composition of rice bran $(6 \%)$, production of phytase was significant. In beginning the phytate degrading enzymes from rice bran were active in the first six hours of the process. Then the bacteria of rice bran start to grow and produce more bacterial phytate degrading enzymes. Production of phytase was significant during the $6^{\text {th }}$ week. The production of phytases started as soon as the cultures entered the stationary phase and it increased in the middle of the 5th week. As phytate in rice bran occurs as a less soluble potassium-magnesium salt, usually combined with protein, or enclosed by starch and other carbohydrates, the rate of rice bran phytate being hydrolyzed could be lower. The lower rate of hydrolysis ensures that phytase production is continuously induced during the whole fermentation process and end-product inhibition is prevented, thus leading to increased phytase production was also reported by Papagianni et al., (1999).

The optimum temperature for the production of phytases from most of the microorganisms lies in the range of 25 to $37^{\circ} \mathrm{C}$ (Vohra and Satyanarayana, 2003) also comes to true in this study of autolysis of rice bran. Awad et al., (2014) also reported that $27{ }^{\circ} \mathrm{C}$ was the optimal temperature for phytase production. The optimum temperature range for incubation of microorganisms for high 
phytase (Gautam et al., 2002). However, optimum temperature for $P$. stewartii to Hussin et al., (2011) found that $33^{\circ} \mathrm{C}$ was the produce phytase.

Fig.1 Change in Temperature during the Production of Phytase in a batch fermentor. Liberation of $\mathrm{P}$ from action rice bran phytase on phytate showed effect on raising the residual temperature from 45 to 53 days

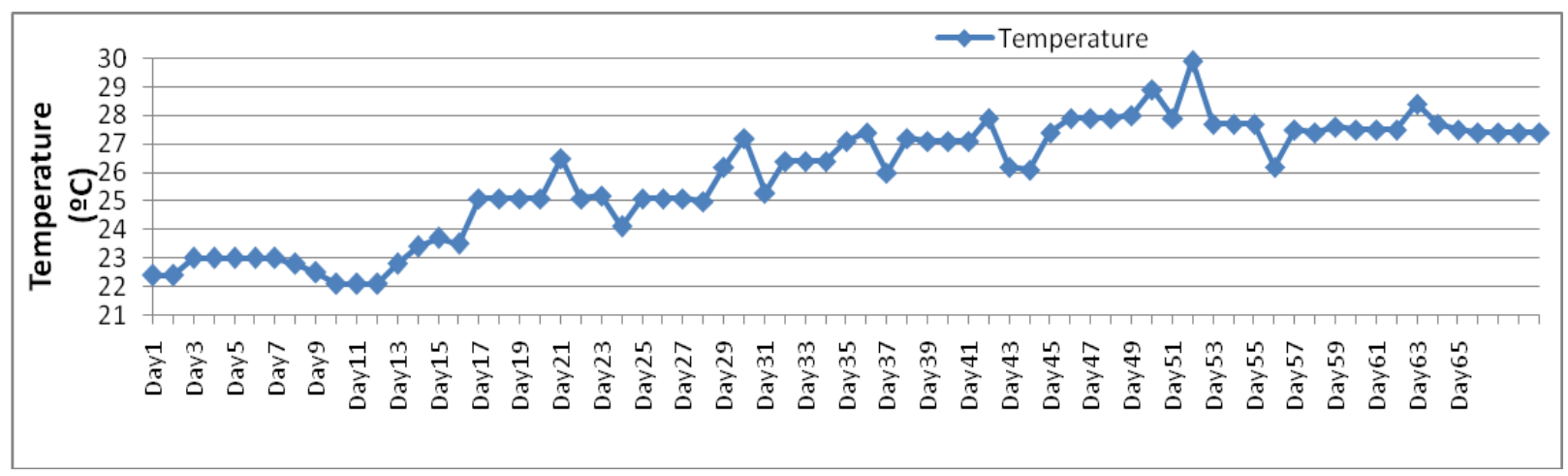

Fig.2 Change in $\mathrm{pH}$ during the Production of Phytase in a batch fermentor indicate the microbial growth (bacterial) during the phytate hydrolysis. The $\mathrm{pH}$ was turned from $\mathrm{pH} 5.0$ to 4.2 (Acidic) during the first 3 weeks. After 3 weeks till 37 days $\mathrm{pH}$ have fast increased to 7.0. During the last 3 weeks till 69 days $\mathrm{pH}$ turned to 7.8 (Alkaline)

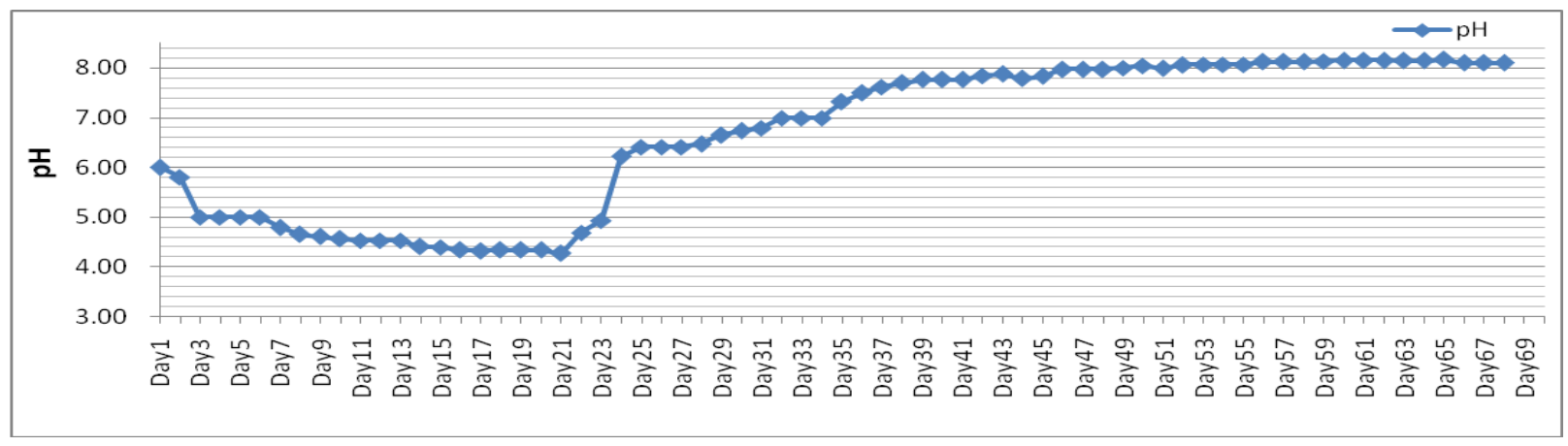

Fig.3 Change in dissolved oxygen (DO) of Rice bran phytase production for 67 days in a batch Fermentation. The DO have decreased after 3 weeks and reach steady low after 57 days

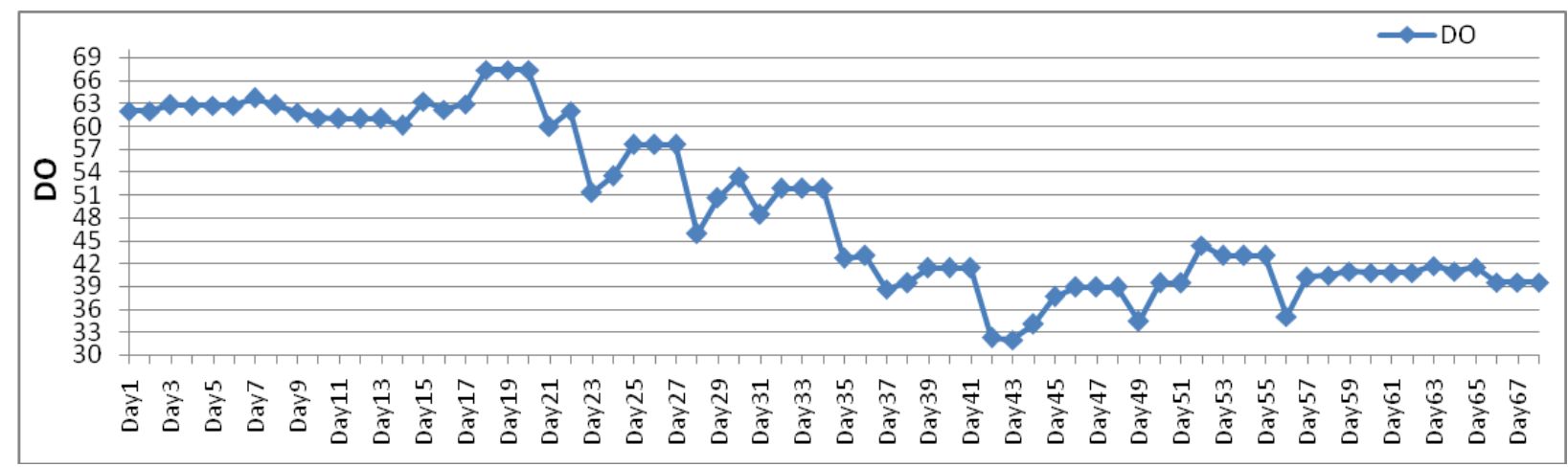


Fig.4 The Optical density at $355 \mathrm{~nm}$ values measured the liberated $\mathrm{P}$ from rice bran during 10 weeks of fermentation process. The highest $P$ was liberated during weeks 6, 7 and 9

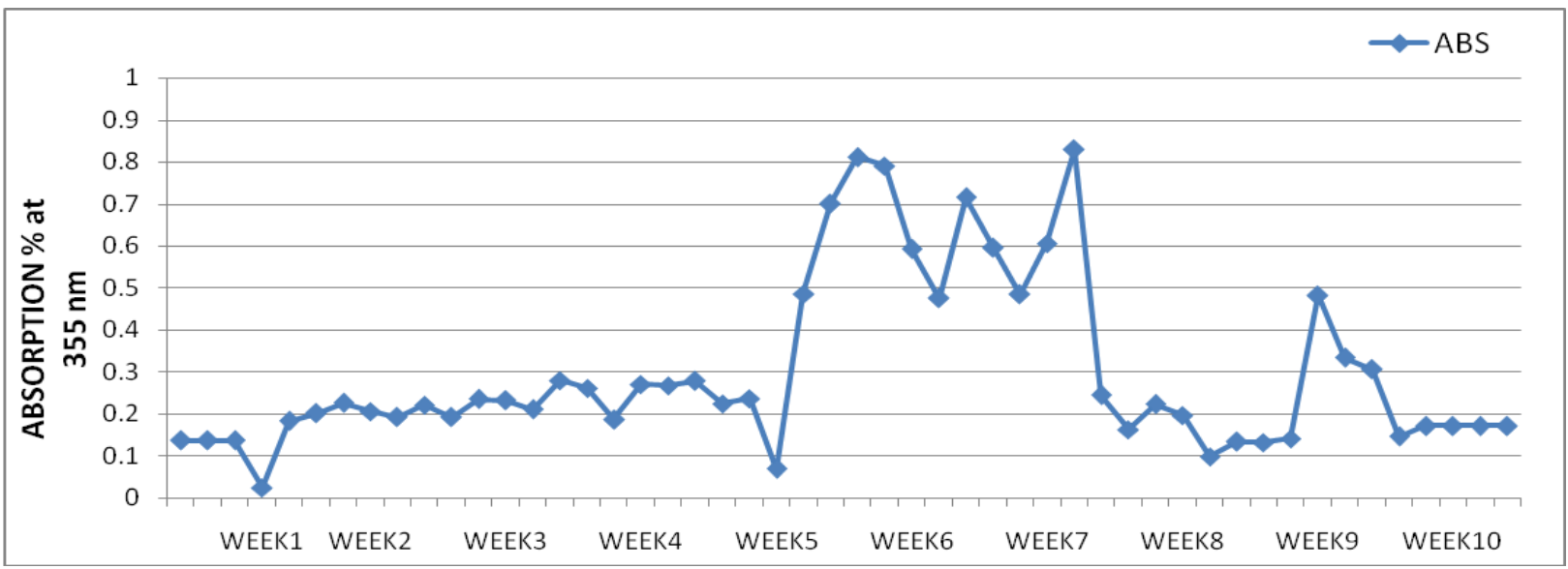

The optimum initial $\mathrm{pH}$ for phytase production of $B$. cereus ASUIA260 was $\mathrm{pH}$ 7.2 (Vohra and Satyanarayana, 2003), the optimum $\mathrm{pH}$ of most bacteria and fungi is in the range between $\mathrm{pH} 5.0$ and $\mathrm{pH}$ 7.0. In this study the optimum value was at $\mathrm{pH}$ 7.5. The stability of most plant phytases decreased dramatically at $\mathrm{pH}$ values below 4 and above $\mathrm{pH} 7.5$, while the majority of the corresponding microbial enzymes are stable even at $\mathrm{pH}$ values above 8.0 and below 3.0 (Greiner and Konietzny, 2006). In our present study the $\mathrm{pH}$ variations were found, above $\mathrm{pH}$ 8 the stability decreased. Most phytases have an optimal $\mathrm{pH}$ in the range of $4.5-6.0$ and a temperature range of $45-60^{\circ} \mathrm{C}$. Outside the optimal range of $\mathrm{pH}$ and temperatures the action of phytase is reduced (Turk et al., 1996).

The majority of the plant phytases are irreversibly inactivated at temperatures above $70^{\circ} \mathrm{C}$ within minutes, whereas most of the corresponding microbial enzymes retain significant activity even after prolonged incubation times (Singh and Krikorian, 1982). The majority of the so far characterized phytases showed maximal phytate-degrading activity in the acid $\mathrm{pH}$ range. Alkaline phytases have been purified from different
Bacillus species. In this study at $\mathrm{pH} 7.62$ a sharp $\mathrm{pH}$ optimum was noticed. Anyhow repeated and further studies required. Enzyme activity increases with temperature up to a maximal temperature. A further increase in temperature results in a heat-induced denaturation of the enzymes. Depending on the enzyme source, optimal temperature for phytate hydrolysis varies from 35 to $80^{\circ} \mathrm{C}$ (Greiner and Konietzny, 2006). In this study the temperature range was $22-29^{\circ} \mathrm{C}$ throughout the experiment. Further study needed to know the behaviors at elevated temperatures.

The Figure 2 shows the $\mathrm{pH}$ at different days and Figure 4 shows the phytase activity. The phytase production was significantly higher at $\mathrm{pH}$ range 7.62. The phytase production was significantly higher at temperature $26^{\circ} \mathrm{C}$. The phytase production was significantly higher at $6^{\text {th }}$ week. Further study can be conducted by increasing/decreasing the rpm of the agitator, changing the dissolve oxygen (D.O) content, $\%$ of rice bran, the volume of the media, changing the impeller design and at elevated temperatures. The nature for phytases with more constructive properties should be studied for food applications and engineering phytases in order to optimize their catalytic 
and stability features are suitable approaches to make a proper phytase available for a specific application in food processing. An improved method for production of phytase and yields can be studied for defatted rice bran/enriched rice bran/at different temperature/varying the periods of fermentation with known concentration of rice bran though many times the concentration has little effect compare to other factors.

\section{Conflict of Interests}

The authors declare that there is no conflict of interests regarding the publication of this paper.

\section{Acknowledgement}

The authors express their gratitude to Taif University, Al-Hawiya 888, Kingdom of Saudi Arabia and the support of the Dean of Science. Also, the authors extend their sincere gratitude for the support of the Biotechnology Department of Taif University, Saudi Arabia for its support for these research efforts.

\section{References}

Anon Enzymes: a market survey. Focus Catal. 2012. 11: 2.

Awad G.E., Helal M.M., Danial E.N., Esawy M.A. 2014. Optimization of phytase production by Penicillium purpurogenum GE1 under solid state fermentation by using Box-Behnken design. Saudi J Biol Sci.; 21(1): 81-88.

Canan C., Lisboa Cruz F.T., Delaroza F., Rubia Casagrande R., Mendes Sarmento C.P., Shimokomak M., Elza Iouko Ida. 2011. Studies on the extraction and purification of phytic acid from rice bran. Journal of Food Composition and Analysis. 24(7):10571063.
Cao L., Wang W., Yang C., Yang Y., Diana J., Yakupitiyage A., Luo Z., Li, D. 2007. Application of Microbial Phytase in Fish Feed. J. Enzyme and Microbial Technol.; 40: 497-507.

Cheryan M.1980. Phytic acid interactions in food systems. Crit.Rev. Food Sci. Nutr., 13: 297-335

Farouk A., Banaja A., Thoufeekahamed N., AlZahrani O., Bazaid S. 2015. Inducible secretion of phytate-degrading enzymes from bacteria associated with the medical plant Rosa damascena cv. Taifi using rice bran. African Journal of Biotechnology 14 ((5): 425-433.

Gautam P., Sabu A., Pandey A., Szakacs G., Soccol C.R. 2002. Microbial production of extra-cellular phytase using polystyrene as inert solid support. Bioresour Technol.; 83(3): 229-233

Grases E., Simonet B.M., Perell J., CostaBauz A., Prieto R.M. 2004. Effect of phytate on element bioavailability in the second generation of rats. J. Trace Element in Med. Biol.; 171: 229-234.

Greiner R., Konietzny U. 2006. Phytase for food application. Food Technol Biotechnol; 44(2): 125-40.

Gujar P.D., Bhavsar K.P., Khire J.M. 2013. Effect of phytase from Aspergillus niger on plant growth and mineral assimilation in wheat (Triticum aestivum Linn.) and its potential for use as a soil amendment. J. Sci Food Agric.; 93(9): 2242-2247.

Heinonen J.K., Lahti R.J. 1981. A new and convenient colorimetric determination of inorganic orthophosphate and its application to the assay of inorganic pyrophosphatase. Analy. Biochem.; 113 : 313-317.

Hussain A.S.M.., Farouk A., Ali A.M., Greiner R. 2010. Production of PhytateDegrading Enzyme from Anis Shobirin MH, Farouk,. Ali A.M., Greiner R. 
Production of Phytate-Degrading Enzyme from Malaysian Soil Bacteria Using Rice Bran Containing Media. $J$. Agrobiotech; 1: 17-28.

Hussin A.S.M., Farouk A., Ali A.M., Greiner R. 2010. Production of phytatedegrading enzyme from Malaysian soil bacteria using rice bran containing media. Journal of Agrobiotechnology. $1,17-28$.

Hussin A.S.M., Farouk A., Greiner R. 2012. Optimization of cultivation conditions for the production of phytate-degrading enzymes by Enterobacter sakazakii ASUIA279 isolated from Malaysian maize root. Journal of Biotechnology and Biodiversity. 3 (2): 1-10.

Hussin A.S.M., Farouk A., Greiner R. 2012. Purification and properties of a phytatedegrading enzyme produced by Enterobacter sakazakii ASUIA279. Journal of Biotechnology and Biodiversity. 1: 17-28.

Hussin A.S.M., Farouk A., Salleh H.M. 2010. Phytate-degrading enzyme and its potential biotechnological application: a review. Journal Of Agrobiotechnology 1: $1-16$.

Hussin A.S.M., Farouk A.E., Ali A.M. 2011. Greiner R. Production of phytatedegrading enzyme from Malaysian soil bacteria using rice bran containing media. J Agrobiotechnol; 1:17-2.

Idris E.E, Farouk A., Greiner R., Bochow H., Borriss R. 2002. Extracellular phytase activity of several Bacillus amyloliquefaciens FZB45 contributes to its plant-growth-promoting effects. Microbiol.; 148 : 2097-2109.

Irving G.C.J., Cosgrove D.J. 1971. Inositol phosphate phosphatase of microbiological origin. Some properties of a partially purified bacterial (Pseudomonas sp.) phytase. Aust. J. Biol. Sci.; 24: 547-557.

Jog S.P., Garchow B.G., Mehta B.D., Murthy
PPN. Alkaline phytase from lily pollen: Investigation of biochemical properties. Arch. Biochem. Biophys. 2005. 440: 133-140.

Konietzny U., Greiner R. 2002. Molecular and catalytic properties of phytase degrading enzymes (phytases). International Journal of Food Science and Technology; 37: 791-812

Kornegay E.T. 1996. Nutritional, environmental, and economic considerations for using phytase in pig and poultry diets. In Nutrient Management of Food Animals to Enhance and Protect the Environment. Lewis Publishers, Washington, U.S.A. Chapter 18, 277-293.

Koshy J.C., Sharabi S.E., Feldman E.M., Hollier L.H., Jr, Patrinely J.R., Soparkar C.N. 2012. Effect of dietary zinc and phytase supplementation on botulinum toxin treatments. J. Drugs Dermatol.; 11(4):507-512.

Lan G.Q., Abdullah N., Jalaludin S., Ho Y.W. 2002. Optimization of carbon and nitrogen sources for phytase production by Mitsuokella jalaludinni, a new rumen bacterial species. Letters for Applied Microbiology. 35 : 157-161.

Ling C., Weimin W. 2007. Application of microbial phytase in fish feed. Enzyme and Microbial Technology. 40: 497507.

Loewus F. 2002. Biosynthesis of Phytate in Food Grains and Seeds. In: Food Phytates, N.R. Reddy, S.K. Sathe (Eds.) and CRC Press, Boca Raton, Florida, USA 53-61.

Moreira J.P., Schmidt Vitti D.M.S., Neto M.A.T., Lopes J.B. 2003. Phytase enzyme in diets containing defatted rice bran for growing swine. Scientia Agricola; 60(4): 631-636.

Mukesh Kumar D.J., Balakumaran M.D., Kalaichelvan P.T, Pandey A., Singh A., Raja R.B. 2011. Asian J. Exp. Biol. Sci. 
2(4): 663-666.

Nayini N.R., Markakis P. 1986. Phytic Acid: Chemistry and Applications. E. Graf (Ed.). Pilatus Press, Minneapolis, MN. 101-118.

Papagianni M., Nokes S.E., Filer K. 2001. Submerged and Solid-State Phytase Fermentation by Aspergillus niger: Effects of Agitation and Medium Viscosity on Phytase Production, Fungal Morphology and Inoculum Performance. Food Technology and Biotechnology. 39: 326.

Paraddo et. al. 2011. In. Fruit \& cereal Bioactives sources, chemistry and applications, CRC Press by Taylor Francis group LLC, p 46.

Reddy N.R. 2002. Occurrence, Distribution, Content, and Dietary Intake of Phytate. In: Food Phytates, Reddy N.R., Sathe S.K., (Eds.), and CRC Press, Boca Raton, Florida, U.S.A. 25-51.

Reddy N.R., Pierson M.D., Sathe S.K., Salunkhe D.K. 1989. Interactions of Phytate with proteins and minerals, in: Phytate in Legumes and Cereals, CRC press, Boca Raton FL; p 57-70.

Reddy N.R., Sathe S.K., Salunkhe D.K. 1982. Phytates in legumes and cereals. $A d v$.

Food Res. 28: 1-92.

Sandberg A.S., Andlid T. 2002. Phytogenic and microbial phytases in human nutrition International Journal of Food Science and Technology. 37: 823-833.

Singh M., Krikorian A.D. 1982. Inhibition of trypsin activity in vitro by Phytate, $J$. Agric. Food Chem. 30: 799-800.
Turk M., Carlsson N.G., Sandberg A.S. 1996. Reduction in the levels of Phytate during whole meal bread making; Effect of yeast and wheat phytases. J. Cereal Sci. 23: 257-264.

Vohra A. and Satyanarayana T. 2003. Phytases: Microbial sources, production, purification, and potential biotechnological applications. Crit. Rev. Biotechnol.; 23: 29-60.

Vucenik I., Shamsuddin A.M. 2003. Cancer inhibition by inositol hexaphosphate (IP6) and inositol: From laboratory to clinic. J. Nutr.; 133 (Suppl.) 37783784.

Weremko D., Fandrejewski H., Zebrowska T., Han K., Kim J.H., Cho W.T. 1997. Bioavailability of phosphorus in feeds of plant origin for pigs. Review. Asian Australas. J. Anim. Sci.; 10(6):541-550.

Wodzinski R.J., Ullah A.H. 1996. Phytase. Adv Appl Microbiol.; 42:263-302.

Yang, W.J. Matsuda Y., Sano S., Masutani H., Nakagawa H. 1991. Purification and characterization of phytase from rat intestinal mucosa. Biochim. Biophys. Acta $;$ 1075: 75-82.

Yusoff M., Noraini and Salleh M., Hamzah and Jamal, Parveen. 2010. Degradation of Phytate in rice bran by local bacteria phytase. Special Issue of Research Journal of Chemistry and Environment. 361-365. ISSN0 0972-0626.Bacteria Using Rice Bran Containing Media, $J$. Agrobiotech; 1:17-28.

\section{How to cite this article:}

Abd-ElAziem Farouk, N. Thoufeek Ahamed, Anis Shobirin Meor Hussin and Othman AlZahrani. 2017. Autolysis of Rice Bran Phytate in Long-Term Study on Batch Fermentor. Int.J.Curr.Microbiol.App.Sci. 6(12): 266-274. doi: https://doi.org/10.20546/ijcmas.2017.612.033 